\title{
DESIGN OF A DECISION SUPPORT SYSTEM FOR IMPROVING AIR QUALITY ASSESSMENT
}

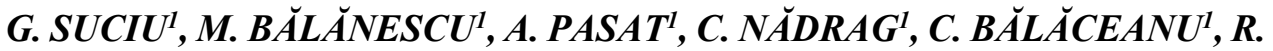 \\ MATEI $I^{1}$ V.SUCIU ${ }^{I}$, A. VASILESCU ${ }^{I}$
}

\begin{abstract}
Design of a decision support system for improving air quality assessment. Establishing a system that allows the transition from environmental and traffic monitoring to environmental management at the personal level has become a necessity. Such a system will improve the life quality, reduce health costs and increase the support of vulnerable groups (i.e., the elderly, children).

ESTABLISH project aims to advance an innovative platform which allows converting environmental (sensor) data into actionable information for users to provide a healthier and safer environment thereby improving the quality of life. Smart adaptive services providing real-time feedback tailored to specific user and application needs will be developed by combining networked sensors and other data sources with adaptive models. This paper will present the on-going research within the ESTABLISH project related to the development of a decision support component which assesses the air quality. Based on real-time monitoring and quantification methods, and certain types of notifications for risk groups and general populations, the proposed system links pollutant concentrations to individual health risks. The proposed decision support for air quality assessment is structured on two components. The first component is represented by the comparison with the limit values provided by the legislation, and the second is the forecast of near-real-time air pollution episodes (based on trigger values). Thus, for each pollutant considered $\left(\mathrm{PM}_{2.5}, \mathrm{PM}_{10}, \mathrm{SO}_{2}, \mathrm{NO}_{2}, \mathrm{O}_{3}\right.$, and $\left.\mathrm{CO}\right)$ the frequency of pollutants concentrations measurement, the averaging periods according to the legislation, the averaging period and the limit values used for the notification component were established.
\end{abstract}

Keywords: smart health, decision support system, air quality.

\section{INTRODUCTION}

The Long-Range Transboundary Air Pollution Convention, concluded in Geneva in 1979, sets a broad framework for the regions of Europe and North America covered by the United Nations Economic Commission for Europe (UNECE) and aims at cooperation in the field of air pollution (UNECE CLRTAP, 1979).

The Geneva Convention is the first international agreement to recognize both environmental and human health issues, problems caused by the transfer of air pollution across borders and the need to find solutions at a regional level.

\footnotetext{
${ }^{1}$ Beia Consult International, Research \& Development Department, 041386, Bucharest, Romania, e-mail: george@beia.ro
} 
Over the past 25 years, emissions of air pollutants in Europe have fallen significantly due to the implementation of environmental policies. Thus, $\mathrm{SO}_{\mathrm{x}}$ decreased by almost $90 \%$ (the highest recorded decrease), the amount of NMVOC reduced by around $60 \%, \mathrm{NO}_{\mathrm{x}}$ emissions dropped to less than half, and fine particulate emissions $\left(\mathrm{PM}_{2.5}\right)$ fell by $33 \%$. The smallest decrease was recorded by ammonia emissions $\left(\mathrm{NH}_{3}\right)$ with $25 \%$ (EU CLRTAP, 2017).

Although the total pollutant emissions values have fallen to EU-28 level, the degree of exposure of the urban population to concentrations exceeding the permissible limit values is high (EEA, 2017). Around $43 \%$ of the EU-28 population was exposed in 2014 to annual average concentrations of $\mathrm{PM}_{10}$ above World Health Organization (WHO) threshold. Concerning $\mathrm{PM}_{2.5}$, around $84 \%$ of the EU28 population was exposed in 2014 to annual average concentrations above the WHO limit. For $\mathrm{NO}_{2}$, in 2014 around 3\% of the EU-28 population have lived in areas with annual average concentrations higher than the EU limit value (EEA, 2017).

Estimates of the health impacts attributable to exposure to air pollution indicate that $\mathrm{PM}_{2.5}$ concentrations in 2014 were responsible for about 399000 premature deaths originating from long-term exposure in EU-28. Europe's pollutants concerning most severe harm to human health are $\mathrm{PM}, \mathrm{NO}_{2}$, and groundlevel $\mathrm{O}_{3}$, (EEA, 2017).

Locally, the $\mathrm{SO}_{\mathrm{x}}$ emissions in Romania fell significantly by almost $75 \%$ in 2015 compared to 2005 , due to the utilization of the low-sulphur fuels and the use of desulphurization equipment for large combustion plants. The state of air quality in Bucharest was addressed in several studies (EEA, 2017), (Iorga et al., 2015), indicating a level of specific pollutants above the maximum limit regulated by the European Union.

According to the statistical data provided and verified by the National Environmental Protection Agency, in 2016 the annual limit value for $\mathrm{PM}_{10}$ was repeatedly exceeded (38 times) at the level of Bucharest city. Other pollutants, such as $\mathrm{NO}_{2}, \mathrm{SO}_{2}, \mathrm{CO}$, ozone $\left(\mathrm{O}_{3}\right), \mathrm{PM}_{2.5}$ and benzene have occasionally reached values close to the maximum allowed. Also, Bucharest is the city where most months of living (22 months) are lost due to exposure to $\mathrm{PM}_{2.5}$, according to a study conducted for 25 major capitals and cities in the EU (Aphekom, 2011).

In this context, there is a real need to find and advance solutions that can mitigate the tragic statistics. The concept behind the ESTABLISH project contribute to reducing the human health effects by converting environmental data into actionable information for users. The section 2 of this paper will put in context the Air Quality Standards which apply to Romania, and describe other AQI (Air Quality Index) that link atmospheric pollutants to health effects. In section 3 are described the design of the decision support system and its components, while in chapter 4 the conclusions are presented. 


\section{AIR QUALITY INDEX}

To tackle air pollution actions at many levels are required, including local air pollution measurements and citizen involvement. For this, it is necessary to provide easy access to air quality information. In Romania, the air quality standards for health protection given in the Law No. 104/2011 (includes subsequent amendments according to Directives 2008/50/EC, 2004/107/EC and 2015/1480) provide only limit values for main pollutants (Table 1). Also, the Romanian Air Quality Index (RO-AQI) are calculated based on concentration values of the pollutants $\left(\mathrm{SO}_{2}, \mathrm{NO}_{2}, \mathrm{O}_{3}, \mathrm{CO}\right.$, and $\left.\mathrm{PM}_{10}\right)$ and provide only an evaluation of the air quality in qualitative terms (i.e. "good", "excellent"). RO-AQI do not offer messages for the general population, at-risk individuals or sensitive groups of people.

Table 1. Air quality standards for the protection of health, as given in the Law no. $104 / 2011$

\begin{tabular}{|c|c|c|c|}
\hline Pollutant & Limit value/target & Averaging period & $\begin{array}{c}\text { No. of exceedances } \\
\text { allowed }\end{array}$ \\
\hline $\begin{array}{l}\text { Particulate matter - } \\
\mathrm{PM}_{2.5}\end{array}$ & $\begin{array}{r}25 \mu \mathrm{g} / \mathrm{m}^{3} \\
- \text { stage } 1,2015^{*}\end{array}$ & 1 year & 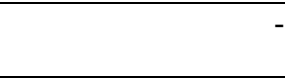 \\
\hline \multirow{2}{*}{$\begin{array}{l}\text { Particulate matter - } \\
\mathrm{PM}_{10}\end{array}$} & $50 \mu \mathrm{g} / \mathrm{m}^{3}$ & 24 hours & 35 times/yeal \\
\hline & $40 \mu \mathrm{g} / \mathrm{m}^{3}$ & 1 year & \\
\hline \multirow[t]{3}{*}{ Nitrogen dioxide } & $200 \mu \mathrm{g} / \mathrm{m}^{3}$ & 1 hour & 18 times/year \\
\hline & $\begin{array}{r}400 \mu \mathrm{g} / \mathrm{m}^{3} \\
-\quad \text { threshold alert }\end{array}$ & $\begin{array}{l}1 \text { hour, for three } \\
\text { consecutive hours }\end{array}$ & - \\
\hline & $40 \mu \mathrm{g} / \mathrm{m}^{3}$ & 1 year & - \\
\hline \multirow[t]{3}{*}{ Sulphur dioxide } & $350 \mu \mathrm{g} / \mathrm{m}^{3}$ & 1 hour & 24 times/year \\
\hline & $\begin{array}{r}500 \mu \mathrm{g} / \mathrm{m}^{3} \\
\text { - threshold alert }\end{array}$ & $\begin{array}{l}1 \text { hour, for three } \\
\text { consecutive hours }\end{array}$ & - \\
\hline & $125 \mu \mathrm{g} / \mathrm{m}^{3}$ & 24 hours & 3 times/year \\
\hline Ozone & $120 \mu \mathrm{g} / \mathrm{m}^{3}$ & 8 hours & 25 days/year \\
\hline Carbon monoxide & $10 \mathrm{mg} / \mathrm{m}^{3}$ & $\begin{array}{l}\text { Maximum daily } \\
\text { average of } 8 \text { hours }\end{array}$ & \\
\hline
\end{tabular}

To establish links between atmospheric pollutants and health effects, in different countries (e.g., U.S, U.K.) air quality indices are used.

The U.S. Air Quality Index (US-AQI) is estimated based on measured values for 6 pollutants $\left(\mathrm{SO}_{2}, \mathrm{O}_{3}, \mathrm{NO}_{2}, \mathrm{PM}_{10}, \mathrm{PM}_{2.5}\right.$ and $\left.\mathrm{CO}\right)$ and includes healthrelated messages, the presentation of sensitive groups of people and messages warning for each pollutant. This air quality index is used to communicate information about real-time air pollution levels and forecasting.

The U.K. Air Quality Index (UK - AQI) recommends intersection points between the value ranges for each pollutant $\left(\mathrm{SO}_{2}, \mathrm{O}_{3}, \mathrm{NO}_{2}, \mathrm{PM}_{10}\right.$, and $\left.\mathrm{PM}_{2.5}\right)$. It also outlines the short-term effects of air pollution on health and the actions that can be taken to reduce the impact. The information accompanying the air quality indices includes specific recommendations for sensitive people groups, along with general recommendations for the population. The association between UK-AQI 
index values and health effects is described in terms of recommendations in Table 2 (COMEAP, 2011).

Table 2. Health Recommendations Accompanying the UK-AQI

\begin{tabular}{|c|c|c|c|}
\hline \multirow{2}{*}{$\begin{array}{c}\text { Air } \\
\text { pollution } \\
\text { banding }\end{array}$} & \multirow[t]{2}{*}{ Value } & \multicolumn{2}{|c|}{$\begin{array}{c}\text { Accompanying health messages for at-risk groups and the general } \\
\text { population }\end{array}$} \\
\hline & & At-risk individuals $* *$ & General population \\
\hline Low & $1-3$ & Enjoy your usual outdoor activities & $\begin{array}{l}\text { Enjoy your usual outdoor } \\
\text { activities }\end{array}$ \\
\hline Moderate & $4-6$ & $\begin{array}{l}\text { Adults and children with lung problems, } \\
\text { and adults with heart problems, who } \\
\text { experience symptoms, should consider } \\
\text { reducing strenuous physical activity, } \\
\text { particularly outdoors }\end{array}$ & $\begin{array}{l}\text { Enjoy your usual outdoor } \\
\text { activities }\end{array}$ \\
\hline High & $7-9$ & $\begin{array}{l}\text { Adults and children with lung problems, } \\
\text { and adults with heart problems, should } \\
\text { reduce strenuous physical exertion, } \\
\text { particularly outdoors, and particularly if } \\
\text { they experience symptoms. People with } \\
\text { asthma may find they need to use their } \\
\text { reliever inhaler more often. Older people } \\
\text { should also reduce physical exertion }\end{array}$ & $\begin{array}{l}\text { Anyone experiencing } \\
\text { discomfort such as sore } \\
\text { eyes, cough or sore throat } \\
\text { should consider reducing } \\
\text { activity, particularly } \\
\text { outdoors. }\end{array}$ \\
\hline Very High & 10 & $\begin{array}{l}\text { Adults and children with lung problems, } \\
\text { adults with heart problems, and older } \\
\text { people, should avoid strenuous physical } \\
\text { activity. People with asthma may find they } \\
\text { need to use their reliever inhaler more } \\
\text { often. }\end{array}$ & $\begin{array}{l}\text { Reduce physical exertion, } \\
\text { particularly outdoors, } \\
\text { especially if you experience } \\
\text { symptoms such as cough or } \\
\text { sore throat }\end{array}$ \\
\hline
\end{tabular}

For some pollutants $\left(\mathrm{PM}_{10}, \mathrm{O}_{3}, \mathrm{CO}\right)$, the averaging periods are relatively long to communicate the air quality information when certain limit values are exceeded. Thus, to predict real-time air pollution episodes, the use of trigger values to complement the air quality index are proposed. In the next section, the trigger values used in the air quality decision component are presented in detail.

\section{DECISION SUPPORT SYSTEM DESIGN}

The life quality improvement system which is developed under the ESTABLISH project aims to assist in the rehabilitation of vulnerable groups of people. This goal can be achieved by combining environmental, physiological and behavioural sensor data and by developing a range of innovative tools to make better decisions and to improve the awareness of prevention factors, (Suciu et al, 2017). The decision support system is the crucial component of the smart health system, the technical architecture proposed within the ESTABLISH project is structured on several levels, as follows:

a) Data presentation level - users can view and interact with the platform's graphical interface (GUI). In GUI design, the main conditions are the compatibility and scalability requirements, with the end product being optimized and usable on various devices and web browsers. Technologies 
such as jQuery, jQuery UI and Modernizr could be used to expand the development framework.

b) Data acquisition level - refers to collecting large amounts of raw data from sensors and other devices (such as Gateways) and storing these data for further analysis and processing. This level is a set of microservices based on specific APIs (Application Programming Interfaces). These microservices are RESTful interfaces that carry structured data from sensors to the level of data persistence. A RESTful web API (also called a RESTful web service) is a web API implemented using the HTTP and REST principles. REST web services will be used as methods for serializing XML or JSON data.

c) Logical level - the decision support component (Data Analysis Service) implements the functionality of the system. This level is responsible for accessing, processing and transforming data, managing data processing algorithms and ensuring consistency and accuracy. The logical decision level is accessed from the presentation layer, to ensure that functionalities are available to users.

d) Data persistence level - refers to data storage and organizing. Due to the data acquisition part of the project, in ESTABLISH data will be stored in two ways (both components of the persistence layer will communicate with the decision support component):

- the data storage component structured as time series - tested through the Graphite solution;

- the data storage component of the activity data type, taken from the portable devices using PostgreSQL databases.

The way all these layers are communicating is presented in Figure 1 below.

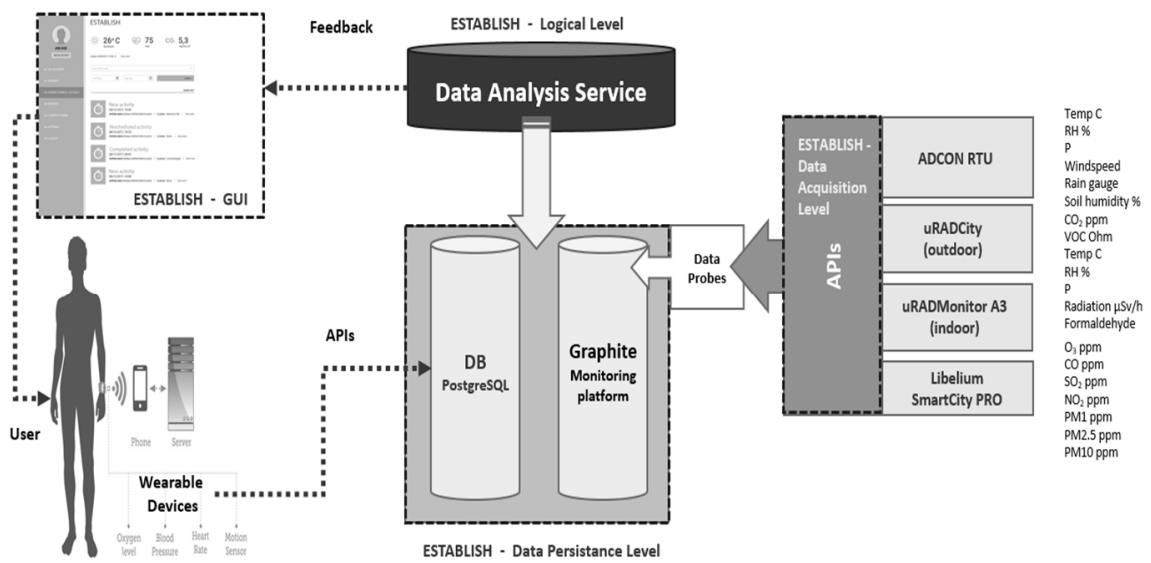

Fig. 1. The block diagram of the ESTABLISH smart health system 
The decision support component is responsible for the associations of pollutant concentrations and health effects. But, for some pollutants, the averaging times are relatively long and represent the main challenge for predicting elevated concentrations in an appropriate timescale. Following the goal for developing the smart health system, this challenge is addressed by two aspects: whether to specify particulate pollution levels in terms of a running or daily average, and whether 'triggers' could be used to give an early indication of a developing air pollution episode. The proposed decision support is structured on two components:

(i) comparison with the limit values provided by the legislation, and

(ii) predicting real-time air pollution episodes (based on "trigger" values).

Table 3. Values used in air quality decision component

\begin{tabular}{|c|r|r|r|r|}
\hline \multirow{2}{*}{ Parameter } & \multirow{2}{*}{$\begin{array}{c}\text { Measuring } \\
\text { intervals }\end{array}$} & \multirow{2}{*}{$\begin{array}{c}\text { Averaging period } \\
\text { for legislative } \\
\end{array}$} & limit value & \multicolumn{2}{|c|}{ Averaging - notification component } \\
\cline { 4 - 5 } & & 24 hours & 60 minutes & $47 \mu \mathrm{g} / \mathrm{m}^{3}$ \\
\hline $\mathrm{PM}_{2.5}$ & 15 minutes & 24 hours & 60 minutes & $67 \mu \mathrm{g} / \mathrm{m}^{3}$ \\
\hline $\mathrm{PM}_{10}$ & 15 minutes & 60 minutes & 10 minutes & $443 \mu \mathrm{g} / \mathrm{m}^{3}$ \\
\hline $\mathrm{SO}_{2}$ & 1 minute & 60 minutes & 10 minutes & $335 \mu \mathrm{g} / \mathrm{m}^{3}$ \\
\hline $\mathrm{NO}_{2}$ & 1 minute & 8 hours & 30 minutes & $135 \mu \mathrm{g} / \mathrm{m}^{3}$ \\
\hline $\mathrm{O}_{3}$ & 1 minute & 8 hours & 30 minutes & $0.011 \mu \mathrm{g} / \mathrm{m}^{3}$ \\
\hline $\mathrm{CO}$ & 1 minute & \multicolumn{3}{c}{} \\
\hline
\end{tabular}

A notification message will be issued if the trigger values will be reached for the two-consecutive averaging period and the second value are higher than first one.

\section{CONCLUSIONS}

Through this paper, the current technological possibilities of advancing an innovative smart health platform that can enrich people's lives by providing valuable information concerning major environmental issues such as air pollution are highlighted.

The research work within the ESTABLISH project show the real need of solutions that can inform people in case of critical conditions, and in long time gain insight over required measures to mitigate the air pollutants.

By analysing several AQI databases and correlating the air pollution concentration to health effects, a trigger notification system which can send alerts at the right time intervals for proper actions was proposed. Aside from the decision support system, the system architecture and communication between all the platform components are presented.

The future work will concern the test field validation of the smart health platform, through a test pilot planned to take place in a high school in Bucharest. 


\section{AKNOWLEDGMENTS}

The work has been supported in part by UEFISCDI Romania through projects ESTABLISH, WINS@HI, SeaForest and CitiSim, by Ministry of Innovation and Research of Romania through POC-5C project and funded in part by European Union's Horizon 2020 research and innovation program under grant agreement No. 643963 (SWITCH project).

\section{REFERENCES}

1. Iorga G., Balaceanu-Raicu C., Stefan S. (2015), Supporting material of annual air pollution level of major primary pollutants in Greater Area of Bucharest. Atmos. Poll. Res.; 6: S1 S18.

2. Iorga G., Balaceanu-Raicu C., Stefan S. (2015), Annual air pollution level of major primary pollutants in Greater Area of Bucharest. Atmos. Poll. Res; 6: 824-834.

3. Suciu G., Vulpe A., Pasat A., Coanca R. (2017), Environmental Sensing and Learning Human Behavior using Cloud Computing and Big Data to act for a better Quality of Life and Smart Health., The International Scientific Conference eLearning and Software for Education, vol. 2, p. 523. "Carol I" National Defence University, Bucharest, Romania.

4. *** (2017), Air Quality in Europe, European Environment Agency.

5. *** (2017), European Union emission inventory report 1990-2015 under the UNECE Convention on Long-range Transboundary Air Pollution (LRTAP), European Environment Agency, Report No 9/2017, ISSN 1977-8449.

6. *** (2017), Raportul privind calitatea aerului în România în anul 2016, Agenția Națională de Protecția Mediului.

7. *** (2017), Romania's Informative Inventory Report, Submission under UNECE Convention on Long Range Transboundary Air Pollution, Revised National Emission Ceiling Directive (NECD), Ministry of Environment.

8. *** (2014), European Commission, September infringements package: main decisions, Brussels.

9. *** (2011), Improving Knowledge and Communication for Decision Making on Air Pollution and Health in Europe, Aphekom project, European Environment Agency.

10. $* * *(2011)$, Legea 104/2011 privind calitatea aerului înconjurător.

11. *** (2011), Review of the UK Air Quality Index, Committee on the Medical Effects of Air Pollutants (COMEAP), U.K.

12. *** (1979), United Nations Economic Commision for Europe, Convention on Longrange Transboundary Air Pollution.

13. https://www.eea.europa.eu/themes/air/intro

14. http://www.adcon.com/products/software-285/adcon-addvantage-6x-1485

15. http://www.adcon.com/solutions/adcon-telemetry-network-110

16. https://www.graphiteapp.org

17. http://www.libelium.com

18. http://www.libelium.com/libeliumworld/meshlium

19. https://www.postgresql.org

20. https://www.uradmonitor.com 